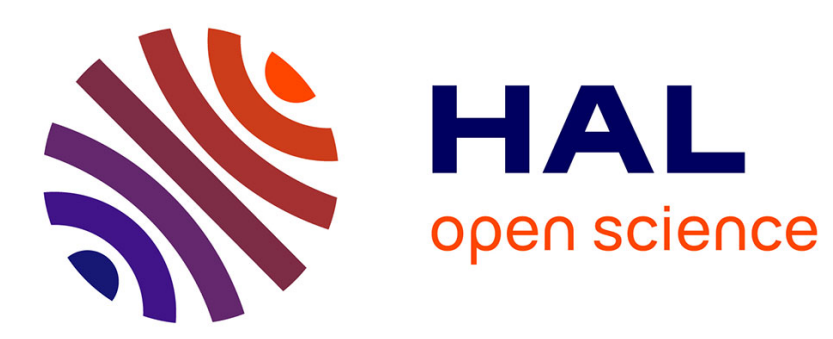

\title{
From free good to commodity: universalizing the provision of water in Paris (1830-1940)
}

Denis Bocquet, Konstantinos Chatzis, Agnes Sander

\section{To cite this version:}

Denis Bocquet, Konstantinos Chatzis, Agnes Sander. From free good to commodity: universalizing the provision of water in Paris (1830-1940). Geoforum, 2008, 39 (6), pp.1821-1832. hal-00520732

\section{HAL Id: hal-00520732 \\ https://hal.science/hal-00520732}

Submitted on 24 Sep 2010

HAL is a multi-disciplinary open access archive for the deposit and dissemination of scientific research documents, whether they are published or not. The documents may come from teaching and research institutions in France or abroad, or from public or private research centers.
L'archive ouverte pluridisciplinaire HAL, est destinée au dépôt et à la diffusion de documents scientifiques de niveau recherche, publiés ou non, émanant des établissements d'enseignement et de recherche français ou étrangers, des laboratoires publics ou privés. 


\title{
From free good to commodity: universalizing the provision of water in
}

\author{
Paris (1830-1940)
}

\author{
Denis Bocquet (CNRS-LATTS), Konstantinos Chatzis (LATTS), Agnès Sander (University \\ of Cergy Pontoise and ENPC-LATTS)
}

Translated from the French by Neil O'Brien

\section{Introduction}

The relationship that any contemporary society has with its past and with its future has varied considerably over time. In order to identify how each society at any given time in its history deals with and presents the temporal dimensions of the past, present and future a French historian, François Hartog, recently forged the concept of "regime of historicity". In Hartog's view, our contemporary societies are beginning to emerge from the "regime of historicity" forged in the wake of the French Revolution which painted the future in terms of progress set against the shortcomings of the present, into another "regime of historicity", characterized by fear of a future (which would appear to be justified) that, far from being bright and rosy, now appears laden with all sorts of threats.

The manner in which the authors of Splintering urbanism interpret the development of infrastructure networks over the long term can be seen in the light of Hartog's work: by contrasting the era of the "modern infrastructural ideal" (that, at least in our view, they tend to idealize - see hereinafter) with the contemporary "splintering" period (fear of the future) the authors are vaguely akin to the "playthings" of the historicity regime change highlighted by Hartog. We consider that the work of Graham and Marvin may be bound up less with a change in network regulatory regime than a change in representation posited by researchers working against the backdrop of a new regime of historicity. Indeed, after analyzing a century (1850-1960) that they deem to have been characterized by progress, and during which, "across the urban world, small, fragmented islands of infrastructure were joined up, integrated and consolidated towards standardized, regulated networks designed to deliver predictable, dependable services across (...) the metropolis" 1 , the two authors nostalgically hark back to this past which they use to assess the present "urban condition", consisting of "splintering urbanism" and "unbundled infrastructure".

Graham and Marvin's stirring account of this golden age in which the "modern infrastructural ideal" emerged and gradually spread throughout the world (or at least the "developed" part of it), takes the form of a major narrative. The story features all types of networks, many

\footnotetext{
${ }^{1}$ Graham (Stephen) Marvin (Simon), Splintering urbanism: networked infrastructures, technological mobilities and the urban condition, London, Routledge, 2002 (first edition 2001), p. 40.
} 
different countries and macro-actors: capitalism (in the Fordist era), the Nation State and the major ideological systems "asserting the positive transformative powers of modern science and networked technologies" 2 . Indeed, the authors are fully aware of the difficulty of the task and point out that "given that we are addressing all networked infrastructures in a wide variety of contexts, it [ the construction of the modern infrastructural ideal] is a huge and complex story. We can merely scratch its surface in this chapter"3.

This article will attempt to delve beneath this surface and to show that Graham and Marvin's reading of the modern infrastructure ideal is an idealized one. In order to do so, we propose to change the scale of research and to focus on just one network (water distribution) and just one city (Paris). We will tackle the period from the 1830s, when most Parisians got their water from public fountains, to the 1930s, by which time almost all of the capital's inhabitants had been hooked up to the same network and enjoyed a standard service (i.e., Graham and Marvin's bundled infrastructure).

We consider it essential to downscale the research field in order to understand the dynamics that underpinned the development of urban networks and the emergence of the "modern infrastructural ideal" in cities. We should state from the outset that, in our opinion, the analytical framework proposed by the authors of Splintering Urbanism is much too broad to provide a clear understanding of the myriad actions that underlay, and went into producing "bundled networks", and that the gaps in this framework leave room for interpretations not covered by the two authors. Let us briefly clarify this point.

In the same way that the "need that we have for certain things cannot determine these in such and such a way", nor "pluck them from nothingness and bring them about" many people agree on the "modern infrastructural ideal", this still does not directly and mechanically produce the concrete practices attributed to it 5 . The analyses proposed by Graham and Marvin need to be completed by a detailed analysis of the entire chain of mediators and mediation thanks to which, in certain circumstances and accompanied by multiple technical, organizational and financial innovations, this ideal actually took form.

We also feel that the analytical categories used by the authors of Splintering Urbanism, such as "the Nation State" or "capitalism", along with their classes and other (macro) social categories, require a certain amount of problemization, or "unblackboxing" to paraphrase Graham and Marvin. Neither the Nation State nor the major social entities (classes, professional groups, etc.) that dot the capitalist production landscape are unchanging seamless monolithic realities. This is illustrated by two examples drawn from our research into the history of water distribution in Paris that the reader will encounter later on in this article. As we shall see, both the municipal engineers who designed and managed the Paris water network and a number of Prefects ${ }^{6}$ within the Seine départment (the de facto mayors of the City of Paris), came out in favor of making subscription to the municipal water supply

\footnotetext{
2 Idem., ch. 2.

3 Ibid., p. 43.

${ }^{4}$ Emile Durkheim, Les règles de la méthode sociologique (1894), Paris, Flammarion, 1988, p. 183.

5 Concerning this issue, see $K$. Chatzis, La pluie, le metro et l'ingénieur. Contribution à l'histoire de l'assainissement et des transports urbains (XIXe-XXe siècles), Paris, L'Harmattan, 2000, p. 43-50.

6 Prefects represent the French State at département level (which is what concerns us here). Between 1800 and 1977, unlike other French cities, Paris was run directly by this French government representative and not by a locally-elected mayor.
} 
compulsory for property owners which obviously helped to boost universalization. However, certain government legal advisors refused to allow local officials to impose compulsory subscription on property owners. The other example concerns the behavior of landlords. They alone could contract subscriptions to connect the buildings that they owned to the water supply and how they acted depended on the circumstances. Obviously an owner will always seek maximum benefit from his property (this is the objective condition of property owners under a capitalist system) and providing running water increases the value of dwellings. However, as we shall see, certain landlords did not connect to the system as they deemed the miscellaneous costs involved to be too expensive. Conversely, others used water subscriptions as a means of attracting "good tenants" and this self-interest contributed to generalizing access to water services in Paris.

Restricting the research field thus emerges as a sine qua non for enlarging the field of actors involved in materializing the "modern infrastructural ideal" (for water services in the case in point). As such, we intend to focus on numerous actors who participated in a positive or a negative manner in the process of providing universal access to running water for the population of Paris. We will analyze the manner in which each actor, in accordance with his constraints and resources, which depend on his social position, was able to conceive of his environment, define objectives, confront problems, make choices and deploy a whole range of frequently innovative practices. ${ }^{7}$ Thus, in order to understand the underlying factors, our task consists in identifying the actors, modi operandi, progress and phases involved in universalizing water services.

Finally, as we have already stated, our analysis is presented in the form of a case study and the question of what general lessons can be drawn from a one-off local study inevitably arises. While we do not wish to get into this thorny issue, suffice it to say that a "case study" does not necessarily have to be used merely to validate or refute a general theory. It can also be used to generate a matrix for producing more generally applicable principles. Indeed, the more detailed the analysis, the greater the chance that it will point up (micro) "processes" and "variables" that may be identified individually in a whole range of domains 8 . The more detailed the analysis, the more issues it raises that may otherwise not have been picked up by more sweeping "macro" approaches.

\section{0-1840: vain attempts to import the "British model"}

Let's go back to the 1820s. As far as Parisian water was concerned, the French Revolution had not yet done away with the Ancien Régime and most city dwellers still got their water from public fountains in much the same way as they had done in the

\footnotetext{
7 Our approach is derived from reflections developed by practitioners of so-called "micro-history". See Jacques Revel, "Microanalysis and the Construction of the Social", in Jacques Revel and Lynn Hunt (eds), Histories: French Constructions of the Past, New York, New Press, 1995, p. 492-502. Concerning the place of microhistory in urban studies, see the survey article by Nancy Stieber, "Micro-history of the Modern City. Urban Space, its Use and Representation", The Journal of the Society of Architectural Historians, vol. 58; $\mathrm{n}^{\circ}$ 3, September 1999, p. 382-391. By delving into Actor Network Theory, Thomas Bender also seeks to highlight the involvement of a wider range of actors in the study of urban achievements. See his "History, Theory and the Metropolis", Center for Metropolitan Studies, CMS Working Paper Series, Nº 005-2006 (http://www.metropolitanstudies.de).

8 Concerning this issue, see Jon Elster, Nuts and Bolts for the Social Sciences, Cambridge, Cambridge University Press, 1989.
} 
eighteenth century ${ }^{9}$. Parisians at this time had two solutions: either they could buy from water carriers who plied their trade selling water that they drew from wells designated by the public authorities (fountains known as fontaines marchandes); or they could take their buckets, saucepans and carafes and go and get it themselves - the rich could always send their servants - wherever the "precious liquid" was to be found in fountains where water could be drawn for free or, until the 1840s, from the River Seine itself.

The situation in London was completely different: here water was much more abundant and several private companies had carved up the city and were already piping water directly to many buildings via a distribution network. By 1820, a third of the capital was being serviced so it is hardly surprising that most engineers from the Paris municipal Service des Eaux (water works) looked to London for inspiration ${ }^{10}$. This department was established in 1807 and run by the municipal authorities on behalf of the Prefect of the Seine who exercised the role of Mayor of the capital until 1977. It was run and mostly staffed by engineers of the corps des ponts et chaussées (roads and bridges engineering corps), i.e., state engineers specialized in civil engineering work ${ }^{11}$.

In the 1820s, both Chabrol, the City Prefect, and the heads of the roads and bridges department, were convinced that to supply Paris with potable running water on a sustainable basis, concessions would have to be handed out to private companies as had been done in London. The role of local government would be to draw up tender specifications that would be used to regulate concession agreements. As part of this process, Charles Mallet, an engineer with the corps des ponts et chaussées, and one of the heads of the Service des Eaux de Paris, traveled to London in 1824 to study the system that had been developed there. We should recall that this same year was marked by the opening of the Ourcq Canal, which was to be one of Paris' major sources of water. Mallet contacted a certain Anderson, an engineer with Grand Junction, one of the seven private

\footnotetext{
${ }^{9}$ For an introduction to the history of water in Paris over the period 1830-1930, see K. Chatzis, "Brève histoire des compteurs d'eau à Paris, 1880-1930”, Travaux et Terrains, n 11, 2006, p. 159-178 (a more detailed version in Italian was published as K. Chatzis, "Breve storia dei contatori dell'acqua a Parigi, 1880-1930", Storia Uurbana, $\left.\mathrm{n}^{\circ} 116,2007\right)$. The work of reference for the nineteenth century is still Ph. Cebron de Lisle, L'eau à Paris au XIXe siècle, Paris, AGHTLM, 1991. For contemporary publications, see: L. Beaumont-Maillet, L'eau à Paris, Paris, Hazan, 1991; I. Backouche, La trace du fleuve. La Seine et Paris (1750-1850), Paris, EHESS, 2000; J. Csergo, Liberté, égalité, propreté. La morale de l'hygiène au XIXe siècle, Paris, Albin Michel, 1988. The following "older" publications are also well worth a look: G. Bechmann, Notice sur le Service des Eaux et de l'Assainissement de Paris, Paris et Liège, Librairie Polytechnique Ch. Béranger, 1900; G. Lemarchand (rapporteur), Conseil municipal de Paris. Etude générale au nom de la $6^{e}$ commission sur : l'alimentation en eau de la Ville de Paris et du Département; les progrès réalisés depuis 1854; etc., Paris, Imprimerie municipale, 1923, and, lastly, G. Bechmann, Salubrité urbaine. Distribution d'eau et d'assainissement, tome 1, Paris, Librairie polytechnique Baudry et Cie, 1898 ( $2^{e}$ édition), especially for the more technical aspects. When we do not specify a source, we are referring to one of these publications. So as not to encumber the bibliography, we will only refer the reader to archival material and other primary literature when the information in question is unavailable elsewhere.

10 Concerning the change in how engineers from the Paris Service des Eaux perceived the London water system - from initial admiration to ultimate rejection -, see K. Chatzis, "Eaux de Paris, eaux de Londres: quand les ingénieurs de la capitale française regardent outre-Manche, 1820-1880”, in I. Gouzévitch et L. Hilaire-Pérez. (eds), Les échanges techniques entre la France et l'Angleterre (XVIe-XIXe siècles). Réseaux, comparaisons, représentations, Toulouse, CNRS-Framespa-Université Toulouse Le Mirail (forthcoming).

11 Concerning the corps des ponts et chaussées, see, inter alia, K. Chatzis and G. Ribeill, "L'espace des carrières des ingénieurs de l'Equipement dans le public et le privé (1800-2000)”, Revue française d'administration publique, $n^{\circ} 116,2005$, p. 651-670.
} 
concession holders in London, who drew up a first draft plan for distributing water in Paris via the Ourcq Canal.

Mallet used this first "English" draft scheme to draw up his own plan. Although he was greatly influenced by what he had seen in London, specifically French considerations were clearly present from the outset. The London private companies reserved relatively small quantities of water for "public service" - this term was a contemporary one and signified supplying water for free fountains, hydrants, government buildings, and road cleaning - and then kept the rest (i.e., the bulk of the water) for private individuals. However, Mallet's project envisaged providing an equal amount of water for "public service" and for private service" - again, this is a contemporary term designating the distribution of water to individuals connected to the network ${ }^{12}$. Other projects were also proposed, including one by Raymond Génieys, another ponts et chaussées engineer, who wanted to use the waters of the Seine (deemed by the engineering community of the time to be of superior quality to those of the Ourcq) for "private service". This project, which was less ambitious as well as being less costly than Mallet's, also defined possible terms and conditions for future concession agreements.

However, until the mid-1830s, all of the various different projects for distributing water in Paris remained on hold ${ }^{13}$ and the City failed to attract the private investors that might be interested in securing a concession. In the absence of any private initiatives, the City engineers began to apply themselves to the task of distributing the waters of the Ourcq Canal in the mid-1830s. For the entire period covered by this article water distribution in the capital was the preserve of the Service des Eaux de Paris and of the roads and bridges engineering corps.

It was around this time, i.e., when work first began on the scheme to distribute water from the Ourcq, that a desire to create a Parisian approach that was different from that taken in England first emerged. Although the principle of developing an extended network to pipe water into private dwellings was definitively adopted by the city engineers, granting concessions to one or more private companies was presented by these same engineers as a grave danger for both Paris and its population. Thus, Henry Emery (1789-1842), head of the Paris water department from 1832 to 1839 , openly delighted in the failure of all attempts to grant private concessions in the years after 1810 (the last attempt dates from the mid-1830s). The wave of joint-stock limited partnerships in the mid-1830s and the speculation abuses that surrounded them became a major source of concern to French legislators ${ }^{14}$, and helped to take the shine off the "London model": private companies were depicted as "speculators out to get all consumers (...), banning the poor from free water fountains (...), depriving cities of monumental fountains and all large scale municipal consumption, and putting a squeeze on industry or even exploiting it through

\footnotetext{
12 To be more precise, "private service" also included supplying a number of fountains known as "fontaines marchandes", i.e., fountains fitted with filters and run by the municipality or by private operators, where water carriers could pay to fill their barrels and private citizens could get water for free "by the bowl".

13 Concerning these various projects, see Ph. Cebron de Lisle, L'eau à Paris...., op. cit., et K. Chatzis, "Eaux de Paris, eaux de Londres...”, op. cit.

14 See L. Epsztein, L'économie et la morale aux débuts du capitalisme industriel en France et en GrandeBretagne, Paris, Armand Colin, 1966; A. Daumard, La bourgeoisie parisienne de 1815 à 1848 (1963), Paris, Albin Michel, 1996, p. 427-440.
} 
monopoly practices"15.

\section{The 1840s and 1850s: the first universalization (with a small "u) based on street fountains}

Subsequent events served to confirm and even reinforce this change in perception of the British "art" of distributing water, particularly the influx of a new generation of engineers from the corps des ponts et chaussées) that swelled the ranks of the Paris water department ${ }^{16}$. These engineers, who had a much sounder grasp of mathematics and hydraulic science than Mallet's generation and were confident that they could do just as well or even better than any private company, gradually developed a number of original management tools and invented new practices that enhanced the performance of the capital's water distribution network. Thus, beginning in the 1840s, an "information system" provided a complete mapping, house-by-house and street-by-street, of the state of water distribution in Paris. Each piece of hydraulic equipment was identified and an "information sheet" drawn up for every building 17 . Throughout the 1840-1940 period, the capital city's engineers and politicians used this system, which was a sort of "Benthamian panoptic", to guide water policy (establishing priority connections and other work, etc.). We should also mention the pioneering work of the engineer Dupuit, head of the Paris department of public works in the middle of the nineteenth century, who proposed optimal design for the network based on the laws of hydraulic science ${ }^{18}$.

Thanks to the efforts of Emmery and pressure from inhabitants themselves ${ }^{19}$, "public service" developed in quite a spectacular manner, leading to what may be considered the first phase in generalized access to water - albeit access with a small "a", mostly via street fountains. Emmery decided to allow the public to use the water initially earmarked for street-washing purposes, and to install small public fountains (known as bornes-fontaines) in almost every street. This decision was validated by the Municipal Council in 1833. The number of such fountains soared from 124 in 1823 , to 1,020 in 1839 , and to 1,779 in $1854^{20}$. As a result, by the middle of the century, practically all Parisians had access to a street fountain close to their home. The quantities of water distributed also increased exponentially, from less than 10 liters per inhabitant per day at the beginning of the century, to 60 liters in 1850 (all uses combined, i.e., private consumption, street cleaning etc. $)^{21}$. We may talk in terms of a first form of

\footnotetext{
15 Cited by Ph. Cebron de Lisle, L'eau à Paris...., op. cit., p. 182.

16 In 1840, three of these engineers had been allocated to the water and sanitation department. By 1887, this number had risen to 23. These figures are taken from Annuaires annuels du corps des ponts et chaussées.
}

17 H.C. Emmery, Statistique des eaux de la Ville de Paris (année 1839), Paris, Carilian-Goeury et V. Dalmont, 1840.

18 See Jules Dupuit, Traité théorique et pratique de la conduite de la distribution des eaux, Paris, CarilianGoeury et V. Dalmont, 1854.

19 See, for example, the requests and petitions submitted by the inhabitants of the district of Saint-Martin for the period 1840-49: Archives de la Seine: AS, VO3, 688.

20 Ph. Cebron de Lisle, L'eau à Paris..., op. cit., p. 200 et 202.

21 Idem, p. 99 and 386. 
universal access to water and while it was modest in terms of today's "universalization", it was still highly significant for the period.

Alongside this first form of "universalization" via public fountains, the Paris water department also tried to develop a system for signing up private individuals as subscribers: this concerned "private service" (to continue in the parlance of the period), and it was the only means of bringing in revenue to operate and fund the development of the infrastructure, including completing the system of street fountains. Thence the fee-based "private service" helped to partially fund the "public service" which was free of charge. At this time, Parisians who wished to have running water in their homes could either subscribe on a free-flow basis they received an unlimited quantity in return for a flat rate charge - or using gauging - a daily quantity of water was provided based on the amount of their subscription. However, subscriptions were slow to take off. In 1854, only 6,229 buildings had signed up (plus 1,165 industrial buildings, 137 public baths and 102 washeries), which was less than a fifth of all dwellings in the capital at this period. Meanwhile, London in the 1850 s - a city serviced by several private companies - boasted a take-up rate in excess of $90 \%$. In actual fact, Parisian property owners, who were the only real potential subscribers, were frequently reluctant to connect to the city distribution system. This was due less to the direct costs involved (connection costs) than to the increased cost of emptying cesspools: the more water tenants used, the quicker the cesspools filled up, and the more landlords had to pay to have them emptied (this was how Paris' sewage system worked at this time).

Consequently, in the early 1850s, the volume of water distributed in Paris via the private service network was about four or five times less than that supplied through the different types of free fountain ${ }^{22}$. Practically all of this water came from either the Ourcq Canal or the Seine - the canal alone provided $3 / 4$ of all production. We should note that water for "private service" provided from the Seine, deemed to be of superior quality at this time, was much more costly than that from the Ourcq (up to 8 times more expensive until 1846, and about twice as expensive thereafter). Consequently, subscriptions using gauging were mainly applied to water drawn from the Seine. Lastly, the quality of the water distributed through the paying private service was no better than the water freely available from street fountains.

This global data needs to be augmented by more detailed information. For example, in 1854 , the average Parisian consumed 23 liters of water a day, the network subscriber consumed 46 liters, while those that drew it from the fountains used only 18 liters on average ${ }^{23}$. Such disparities relating to the means of access to water were coupled with significant "spatial" disparities. For example, in the old Seventh arrondissement (municipal district) ${ }^{24}$, at the end of the 1840s, there was only one public fountain/standpipe per 800 inhabitants, whereas the old Fourth arrondissement ${ }^{25}$ had one for every 240 inhabitants. The same sort of analysis

\footnotetext{
$22 \mathrm{Ph}$. Cebron de Lisle, L'eau à Paris..., op. cit., p. 202-203.

23 J. Csergo, "L'eau à Paris au XIXe siècle: approvisionnement et consommation domestique”, in F. Caron, J. Dérens, L. Passion et P. Cebron de Lisle (eds), Paris et ses réseaux: Naissance d'un mode de vie urbain, XIXeXXe siècles, Paris, Hôtel d'Angoulême-Lamoignon, 1990, p. 150.

24 Corresponding to the southern portion of today's $3^{\text {rd }}$ arrondissement and the northern portion of the $4^{\text {th }}$ arrondissement (i.e., those drawn up after 1860 - see hereinafter).

25 Corresponding to the eastern portion of what became the First arrondissement after 1860.
} 
points up similar disparities in respect of subscriptions. In 1849, the neighborhoods of the Left Bank (the old Tenth, Eleventh and Twelfth arrondissements ${ }^{26}$ ), despite being much poorer, had 2,100 subscribers out of a city-wide total of 5,300, i.e., one concession for every 230 inhabitants, instead of 210 on the wealthier Right Bank ${ }^{27}$. So, is it possible to detect clear patterns between inequalities concerning access to water - in terms of the quantity available, measured for example by the number of fountains per inhabitant, as well as in terms of the quality of the water distributed - and the social geography of the capital ${ }^{28}$ ? In light of the data available, the answer is far from being a clearcut one. Thence, the wealthy Second arrondissement ${ }^{29}$ had just as few public fountains as the poorer Seventh arrondissement (780 and 800 inhabitants per fountain, respectively). Due to topographical reasons and certain contemporary features of the distribution network (problems with water pressure), Left bank neighborhoods (the poorer bank of the Seine) were provided exclusively with water that was actually considered to be of superior quality, and thus more expensive. Consequently, as far as "private service" is concerned, the quality of the water (and the corresponding charges) were more a reflection of topography than the result of any explicit economic, political or social policies.

Thus, at the beginning of the $1850 \mathrm{~s}$, the situation was a contrasting one: the transition to "private service" commodification had begun, while at the same time a first attempt had been made to provide a "universal service" based on free access to street fountains 30 .

The problem for the next generation of city engineers and politicians was to complete the transition to a standard quality service provided to all homes and in order to do this, they had to find the investment required to bring high quality water to Paris and to distribute it throughout the urban territory.

But they also had to find a way to get around the reluctance of property owners to connect their properties to the water network. Indeed, we may wonder, along with the engineers themselves and the members of the municipal council at the time, whether the high spatial coverage ratio already provided via the public fountains (universalization with a small "u") actually stymied the development of "private service": why pay to become a subscriber when water was available free-of-charge just outside the door? Paradoxically, those who could most afford to become subscribers, i.e., the better off, were the least enthusiastic as they could either get water carriers to deliver it to their door or send their servants to fetch it from the public fountains ${ }^{31}$. We should also note that servants themselves did not appear any more

\footnotetext{
26 Roughly corresponding to today's Sixth and Seventh arrondissements and part of what became the Fifth arrondissement after 1860 .

27 See Sari (Rapporteur), Mémoire sur la distribution des Eaux dans Paris..., Paris, 1852.

28 Concerning the social geography of Paris, see B. Marchand, Paris, histoire d'une ville (XIXe-XXe siècle), Paris, Ed. du Seuil, 1993; the best mapping of Paris' social geography in the 1840s is still provided in $A$. Daumard, op. cit., p. 181-218.

29 Corresponding to the bulk of the present-day Ninth arrondissement (apart from its eastern extremity), as well as a portion of today's First and Second arrondissements.

30 As we have seen, there were spatial disparities in the provision of this "universal service". For detailed streetby-street information on the spatial distribution of the fountains, see Revue municipale (31 décembre 1850, 1er septembre 1852, 16 décembre 1852, 1 septembre 1853, as well as the May 10, 1882 meeting of the Conseil municipal de Paris.

31 For example, this was the reason put forward by the engineers Aubuisson and Darcy, the heads of the water boards of Toulouse and Dijon, respectively, in the 1830s and 1840s, to explain the low subscription take-up rate
} 
eager to have it brought into the places where they worked. If the building was not connected to the network, the water carrier took it up to the kitchen, whereas, if it was, the servants had to go all the way down into the yard (at this time the water from the network only ever went as far as the ground floor) and then haul it back upstairs themselves! 32.

All of these questions were being asked from the beginning of the 1830s within the various municipal departments. When Emmery, who had been a major advocate of public fountains, was made head of the Paris water department, he had to face down his own staff who had gradually begun to replace the few existing public fountains intended mainly for street cleaning purposes, by a new model located on the sidewalk and designed specifically to prevent the possibility of drawing water for private use. These measures set off bitter debates that lasted for years. Certain people were delighted that limiting the use of public fountains had boosted subscriptions to the network, while others deplored the fact that these same measures were pushing the poor onto the sidewalks to siphon off their drinking water from street cleaning taps ${ }^{33}$.

\section{Table 1}

\section{Population of Paris (census)}

\begin{tabular}{|l|l|l|l|l|l|l|l|}
\hline Year & 1801 & 1831 & 1856 & 1861 & 1881 & 1901 & 1936 \\
\hline Inhab. & 546856 & 785866 & 1174346 & 1696141 & 2269023 & 2714068 & 2829746 \\
Bontaines & & $(1830)$ & $(1854)$ & $(1860)$ & $(1889)$ & & Fin des \\
(ordinaire & 146 & 1779 & 1780 & 1044 & années \\
s plus à \\
repoussoir
\end{tabular}

in the two cities, both of which were well-equipped with public fountains. See, K. Chatzis et O. Coutard, "Dupuit à propos du mode de distribution et du prix de vente des eaux aux particuliers", in J.-P. Simonin et $F$. Vatin (dir.), L'œuvre multiple de Jules Dupuit (1804-1866). Calcul d'ingénieur, analyse économique et pensée sociale, Angers, Presses Universitaires d'Angers, 2002, p. 79.

32 L. Beaumont-Maillet, L'eau à Paris, op. cit., p. 168.

33 See Louis Lazare, Les quartiers de l'Est de Paris et les communes suburbaines, 1870 


\section{Sources}

Population: A. Fierro, Histoire et Dictionnaire de Paris, Paris, Robert Laffont, 1996, p. 279.

Nb des abonnements : années 1840 1855, 1900 (Ph. Cebron de Lisle, «Les eaux et les égouts à Paris au XIXe siècle. Evolution technique », dans F. Caron, J. Dérens, L. Passion et Ph. Cebron de Lisle (dir.), Paris et ses réseaux : naissance d'un mode de vie urbain, XIXe-XXe siècles, Paris, Hôtel d'Angoulême-Lamoignon, 1990, p. 116) années 1861, 1881 : J. Csergo, Liberté, égalité..., op. cit., p. 326 ; année 1927 (K. Chatzis, « Brève histoire... », op. cit., p. 169).

Nombre de fontaines : Lemarchand Georges, Conseil municipal de Paris, étude au nom de la 6ème commission, 1923 et J. Csergo, Liberté, égalité..., op. cit., p. 324.

\section{The Haussmannien era (1853-1870)}

In 1853, Baron Haussmann, one of Napoleon III's leading officials, became Prefect of the Seine Département (Paris) and remained in this position until the fall of the Second Empire in 1870. During his reign, Paris as a capital city underwent enormous changes, both in terms of its morphology and institutional organizations. This whole process took place against a backdrop of a tightening of the State's grip on municipal institutions, however the period was also a heady time for the State elites, especially for roads and bridges engineers working in the municipal departments.

Haussmann's views on developing water distribution in Paris are detailed in two "mémoires" presented to the municipal council in 1854 and 1858 . He favored using spring water to modernize water distribution in Paris. The Seine was no longer considered the best solution although the debate among specialists was inconclusive, as illustrated by the position of the engineer Jules Dupuit, head of the Municipal Department of Public Works, who continued to advocate the use of water from the Seine ${ }^{34}$.

Secondly, Haussmann also decided to split the water supply network in two according to where the water came from: a "private service" for subscribers using spring water only, and a "public service" using waters of inferior quality (from the Seine and Ourcq) for washing streets and industrial purposes. However, this decision, which was to shape the history of water distribution in Paris for the next century, did not eliminate the existing ambiguities once and for all, particularly given the extremely long transition period for such major public works $^{35}$.

It appears that Haussmann would have liked to introduce the principle of compulsory subscription, following the examples of London or Montreal, but even powerful figures within an authoritarian State have to contend with what he called the "national spirit". In the

\footnotetext{
34 Concerning the conflict between Dupuit and Haussmann, see K. Chatzis et O. Coutard, "Dupuit à propos du mode de distribution...", op. cit., p. 84.

35 In $1875,40 \%$ of houses connected to the water distribution network received spring water; this figure was over $80 \%$ in 1887 but it wasn't until the end of the century that spring water was available in all Parisian homes. See J. Csergo, “ L'eau à Paris au XIXe siècle...”, op. cit., p. 143, containing indicative charts by arrondissement for 1879 showing the breakdown of water in Parisian water pipes by source (Seine, Ourcq, etc.) (p. 143-144).
} 
same way that you can't force people to send their children to school, he deplored, neither can you force them to live in decent conditions! 36

The third great change overseen by Haussmann concerned the administrative boundaries of the capital city and the annexation of a series of peripheral municipalities (or at least part of them) in 1860. Thus, Haussmann's decisions concerning water distribution had to be implemented in this new bigger Paris: the city's area doubled and the number of inhabitants increased from 1 million to 1.4 million, so the cost of carrying out the work required to lay on spring water for the city's entire population increased in consequence.

This annexation also impacted the City's water politics in another way. In the years and months preceding the annexation, undoubtedly in anticipation of just such a prospect, several municipalities in the banlieue (suburbs) to be annexed handed out concessions to a private company, Compagnie Générale des Eaux (CGE) created in $1853^{37}$ to run their water services. Once the new areas had been incorporated, a very specific legal problem arose: what would happen to CGE's rights in the formerly independent areas of the new Paris?

The deal proposed (planned in advance?) by Haussmann is very interesting as it reflects many of the specific features of the French hybrid public utility model. It amounted to both a "municipalization" and a (partial) privatization:

1) Municipalization: the Parisian municipal Service des Eaux acquired the entire water infrastructure of the formerly autonomous municipalities from CGE.

2) Privatization: CGE was granted a concession in the new bigger Paris, not for producing or distributing water, nor for managing the infrastructure, all of which remained firmly in municipal hands, but for commercializing municipal water, i.e. handling relations with subscribers. Water commodification in Paris was to be developed by a private company on behalf of a municipal department. CGE was to be a sort of "sales agency" tasked with selling water from the municipal network to Parisians. But, according to Municipal Councilor, Denys Cochin, it also appears to have been assigned the more vague, unspecified task of "stepping in when subscribers were dissatisfied and taking the flak on behalf of the City Council", 38 . And indeed there was no shortage of such flak throughout the nineteenth century whenever service quality fell far short of subscriber expectations (interruptions in supply, replacement of spring water by river water when supplies got low, etc. ${ }^{39}$ ).

So, how effective was the decision to entrust the commercial operations (marketing) to a private firm for the purpose of boosting the number of subscribers? Although it is hard to say

\footnotetext{
36 See: "Second mémoire sur les Eaux (1858), in Documents relatifs aux Eaux de Paris, Paris, Paul Dupont, $1861, p$. 237. This rhetoric was used once again in a symmetrical manner a few decades later by those advocating the compulsory subscription principle after schooling had indeed been made compulsory (see below).

37 See: Jacquot (A.), “La Compagnie Générale des Eaux, 1852-1952”, Entreprises et Histoire, 30, 2002, p.3244.

38 D. Cochin, Paris, quatre années au Conseil Municipal, Paris, Calmann Levy, 1885, p. 246.

${ }^{39}$ See the information contained in the reports filed in the Archives de la Seine: inter alia AS VO NC 198.
} 
exactly what was down to network extension 40 and what was due to the actions carried out by the company, the trend in the 1860s was definitely positive (see Table 2). Indeed, there was a considerable increase in both the number of subscribers and the average daily consumption of water (132 liters per inhabitant per day in 1874 .

Table 2

Entries (Francs) 1860-1869

\begin{tabular}{|c|c|c|c|c|}
\hline & $\mathbf{1 8 6 0}$ & 1861 & 1865 & 1869 \\
\hline Subscribers & 14289 & 20292 & 28963 & 37688 \\
\hline $\begin{array}{c}\text { Entries } \\
\text { (Francs). }\end{array}$ & 1731917 & 2967358 & 5030863 & 6273632 \\
\hline
\end{tabular}

Source : Bechman, Annuaire statistique et descriptif.

Here again, a more detailed analysis shows that this increase in the number of subscribers was marked by major social and spatial disparities in terms of access to water. In 1874, throughout Paris as a whole, only one house in two had taken out a subscription with the municipal water department ${ }^{41}$. The municipal statistics of 1872 show that in the first eleven arrondissements of the new enlarged Paris, i.e., those corresponding to the older, wealthier part of the city, $82 \%$ of houses had subscribed, against a meager $48 \%$ in the other nine arrondissements that mostly comprised the predominantly working class areas annexed in $1860^{42}$.

Under the Second Empire (1852-1870), Paris embarked upon a new "service" era. It had emerged from the first period of "universalization" with a small " $u$ " (based on street fountains), and even though we were still a long way from the contemporary notion of universalization, based on commercial domestic subscriptions to on-tap spring water (universalization with a capital "U”), the broad lines had already been traced out.

Then, just as the water situation in Paris began to improve, the City broke with its suburbs. The agreement of 1860 between the municipality and CGE stipulated that the latter would deal with the new suburban districts as the authorized representative of the City of Paris, however, following an 1869 amendment, this provision was dropped and the municipality

40 Between 1852 and 1870, more than 153 million francs in public funds were invested in the water and sewerage infrastructure. Under Belgrand, head of the water department, an additional $842 \mathrm{~km}$ of new pipes were laid to supplement the $705 \mathrm{~km}$ that previously existed in "the old Paris". See M. Carmona, Haussmann, Paris, Fayard, 2000, p. 521-523.

41 Ph. Cebron de Lisle, L'eau à Paris..., op. cit., p. 386.

42 See also the maps showing water consumption by arrondissement and by inhabitant for the period August 1882-January 1883 presented by J. Csergo in Liberté, égalité..., op. cit., 340. 
waived all previous agreements that it had contracted with the outlying suburban districts. Consequently, while CGE was only allowed to develop its commercial activities in the new Paris (where the municipality maintained strict control over its water resources), in the suburbs from which the City had withdrawn completely, the company now had a free hand, i.e., not merely to market services but to operate the network itself ${ }^{43}$. Thus, by focusing its efforts to provide universal access to a modern network only within its new administrative boundaries, the city authorities appeared to have "forgotten" or even "excluded" suburbanites from this same universalization process.

\section{0-1930: universalization with a capital " $U$ "}

It soon became clear that the undoubted achievements of the Haussmann era were not enough and by the end of the 1870s the City Council had to urgently meet a number of different water policy objectives simultaneously.

From a quantitative perspective, it had to provide ever increasing volumes of water driven by a number of factors, inter alia population growth (see table 1), an increase in consumption patterns for reasons of hygiene and cleanliness mainly attributable to the rapid development of the hygienist movement 44 , economic development, increased traffic and the more widespread use of tar macadam for streets as well as the additional contingent cleaning requirements, and the extra water required for fire fighting activities. A report presented to the Municipal Council in 1880 set a production target of $480,000 \mathrm{~m}^{3}$ per day covering all domestic and nondomestic requirements. We only have to compare this figure with the $300,000 \mathrm{~m}^{3}$ available during a typical dry period to gauge the work that still needed to be done ${ }^{45}$. This quantity imperative was coupled with quality requirements, as previously expressed by Haussmann. Faced with the frequent outbreaks of typhoid fever and cholera that persisted until the end of the century 46 , the municipality wished to provide households with quality drinking water. Based on the criteria of the time, this meant spring water or, if this was not possible, treated river water 47 , both commodities being a "precious" commodity that was increasingly costly to produce and distribute. The end of the 1870s also witnessed completion of the distribution network needed to lay on such quantities of water and as Map $\mathbf{1}$ (water pipes to be laid in 1879), shows, further extensions were required, especially to the territories annexed in 1860 .

\footnotetext{
43 V. Claude, "Une coopération politique dans une mosä̈que urbaine, le cas du service de l'eau en banlieue parisienne (1880-1923)”, Genèses, 65, décembre 2006, p. 92-111.

44 Pierre Bourdelais (ed.), Les hygiénistes. Enjeux, modèles et pratiques (XVIII-XXe siècles), Paris, Belin, 2001. 45 Ph.Cebron de Lisle, L'eau à Paris..., op. cit., p. 501.

46 Notably, the outbreaks of cholera in 1884-85 and 1892, and typhoid fever in 1876, 1882, 1894, 1898-99 and 1900 .

47 The increasing importance of spring water and treated river water is clear from the following figures. In mid1874 maximum production capacity of spring water amounted to 26,000 $\mathrm{m}^{3} /$ day. In 1889 and 1900 the respective quantities were $145,000 \mathrm{~m}^{3} /$ day and $265,000 \mathrm{~m}^{3} /$ day. See $\mathrm{Ph}$. Cebron de Lisle, L'eau..., op. cit., p. 588 et 589. During the particularly hot summer of 1911 , the City of Paris disposed of $360,000 \mathrm{~m}^{3}$ per day of potable water comprising $300,000 \mathrm{~m}^{3}$ of spring water and $60,000 \mathrm{~m}^{3}$ of filtered river water (from the Seine and Marne). Three years later the figures were $325,000 \mathrm{~m}^{3}$ and $140,000 \mathrm{~m}^{3} /$ day, respectively. See L. Beaumont-Maillet, L'eau ..., op. cit., p. 220.
} 


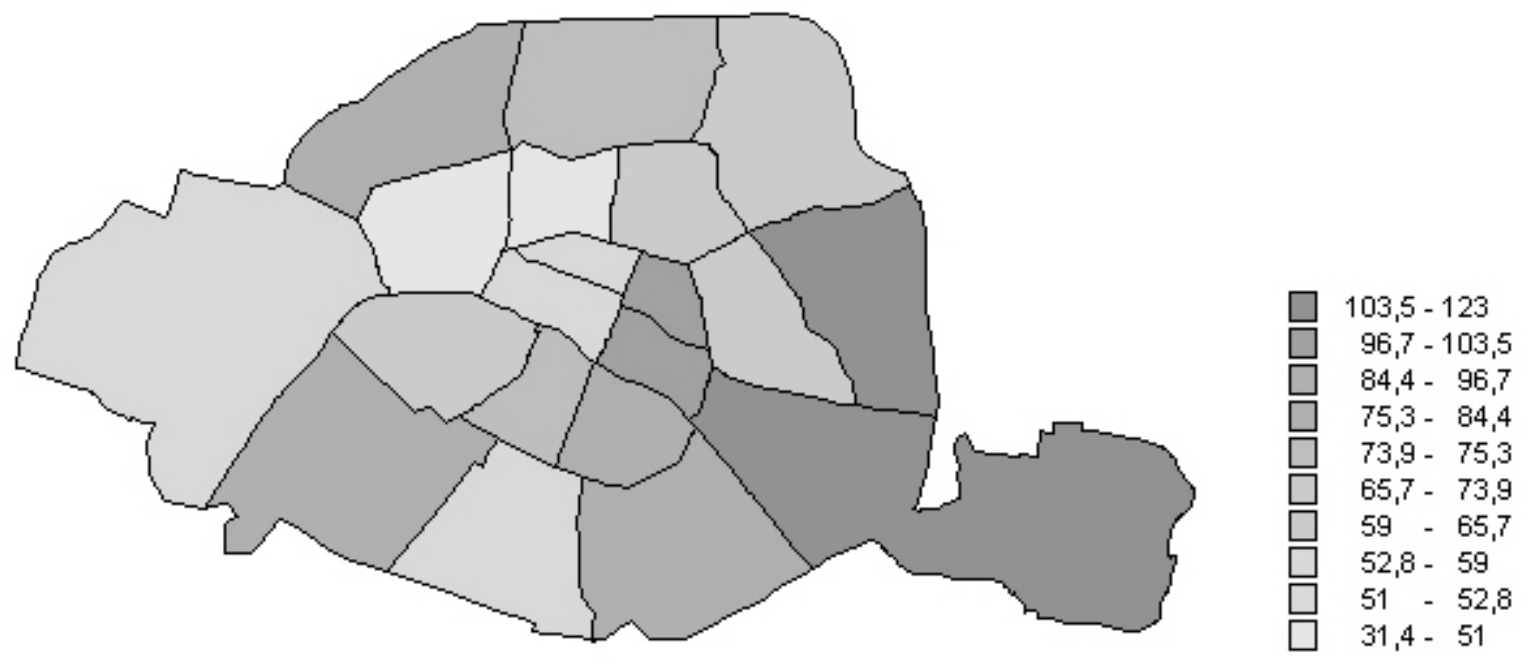

m per hectare

In an effort to boost water subscription rates, municipal officials under the Third Republic first sought to offer lower rates. The debates that took place in the City Council in 1876 and $1877^{48}$ are highly instructive: if we wish to increase the volume of water consumed for reasons of hygiene, especially by poorer people, is it better to lower the rate and double the quantity of water previously provided at the same cost, or to provide subscriptions for lower quantities of water than those provided heretofore? (at this time, subscription agreements stipulated a minimum quantity of water). Thus, the Municipal Council Commission tasked with resolving this issue proposed to scrap subscriptions of 250 liters per day and to replace them with subscriptions of 500 liters "at the same annual charge of 60 francs". The members of the Commission felt that "cutting rates would boost consumption which would offset the fall in revenue" and "help to clean up a large number of workers' dwellings [in the interests of] hygiene and cleanliness, which should take precedence over all other considerations". However, the Prefect of Paris felt that this would represent a huge loss to the municipal coffers and would not be offset by an increase in the number of subscribers. At length, the

48 Meetings of the Municipal Council of December 16, 1876, June 5, 1877 and July 24, 1877. 
Council finally adopted a resolution to provide subscriptions for 250 liters at 30 francs a year (half the previous cost) and to create new subscriptions for 125 liters at an annual rate of 15 francs for buildings occupied by a single household. By adopting this measure, the councilors did not intend to favor the wealthy owner-occupiers of townhouses, but to boost the subscription rate among "small working class households in the annexed suburbs who live alone in a house taken on a long lease, [and who would] gladly take out a subscription for 125 liters at 15 francs a year as proposed by the Commission, but who would be put off by an agreement to take 500 liters of water which would have been the minimum daily consumption for a 60 francs a year subscription under the scheme proposed by the Council". The Prefect of the Seine considered that a subscription of 125 liters ran counter to the principles of hygiene as it did not provide enough water for cleaning purposes. Moreover, he believed that it was the installation costs that dissuaded small property owners from subscribing and not the cost of the water itself. We should note that it is strange that the possibility of setting the subscription price in line with, for example, property values, was never mentioned, especially as this principle had already been applied in other European capitals, inter alia, London. Even though French engineers had regularly visited the British capital ${ }^{49}$, this solution was never seriously envisaged as the engineers themselves thought it much too likely to offend the French "passion" for equal treatment ${ }^{50}$. Notwithstanding, certain municipal charges were calculated using a similar-type model, such as street cleaning charges for which Paris was split up into 7 different categories ( 8 from 1878) based on property values ${ }^{51}$.

It was in the afore-mentioned circumstances that the City of Paris opted for a new subscription method based on the use of meters. Furthermore, in 1871, for the first time in its history, Paris had elected a Municipal Council by universal suffrage and this new body was highly sensitive to anything that was likely to affect the supply of the "precious liquid" to all of the rich and poor citizen-electors of the capital. It was thanks to this new subscription method, which constituted a major innovation at the time - it was not used in London, for example - and necessitated organizational changes on a grand scale 52 , that the universal access to water that we are familiar with today came into existence in Paris ${ }^{53}$.

From the 1870s on, the engineers of the water department were completely in thrall to the use of water meters to which they attributed all manner of virtues. Unlike gauge-based subscriptions, metering did away with all water rationing, thus satisfying the demands of hygienists. Thanks to metering, subscribers could regulate volumes in accordance with seasonal requirements and in the event of a major fire there was now no shortage of water for fire fighting. Unlike the free-flow approach, the meter was presented as the only effective tool for good husbandry (combating waste) of the precious, expensive water that the city wished to distribute, insofar as it was in the interests of subscribers, who now had as much water as they

49 K. Chatzis, “Eaux de Paris, eaux de Londres...”, op. cit.

50 See the accounts provided in K. Chatzis, "Eaux de Paris, eaux de Londres...”, op. cit.

51 Préfecture de la Seine. Direction des travaux de Paris. $4^{\text {ème }}$ bureau. Street cleaning charges from 1879 to 1883 , December 4, 1878. Decree and classification of streets. The detailed classification of Parisian streets in the various neighborhoods, which are discontinuous and presented in the form of lists of streets or street sections, also point up the heterogeneous nature of property values and social distinctions within each city arrondissement.

52 For example, in order to ensure the reliability of the meters being sold on the market, the municipal water department had to set up a municipal hydraulics department.

53 Concerning the history of water meters in Paris, see K. Chatzis, “Brève histoire ...”, op. cit. 
needed, to (auto)regulate their consumption as they had to pay the municipality an amount based, not on a flat rate, but on the quantity actually consumed. The city engineers hoped that the spread in the use of metering would do away with the "irresponsible" behavior of Parisians living in buildings that had subscribed on a free-flow basis. During periods of intense heat, many inhabitants tended to leave the taps on in the hope of cooling their drink as well as the air in their apartment, thus emptying the towns reservoirs and depriving those unfortunate to live in the higher-up neighborhoods ${ }^{54}$. Universal access to the benefits of the network needed to be reciprocated by appropriate behavior on the part of the Parisian consumer, thence the meter appeared as a "disciplinary technology" that guided the behavior of Parisians in the right direction ${ }^{55}$.

At the same time as it brought in the innovative practice of metering for the reasons just referred to, the City also introduced a series of incentives to boost the number of subscribers. After much heated debate, free installation of standpipes to bring water to all floors of the building was offered from 1880 for a three-year period to non-subscriber property owners who agreed to take out a minimum annual subscription (as well as to existing subscribers who agreed to subscribe for additional volumes $)^{56}$. This measure was renewed in January 1884 for an additional three years but apparently failed to produce the expected results: only 2,185 standpipes had been installed by January 1,188657 .

Still in 1880, alongside these incentives, the City undertook a series of restrictive actions. We should mention the ending of free-flow ("free tap") subscriptions for spring water, excluding the upper levels and ground floors of buildings where no trade or industry was conducted. The 1880s were also marked by several attempts, lead by Councilor Déligny with the support of city engineers and the Prefect of Paris, to bring in compulsory subscription ${ }^{58}$ in the same manner as primary school education had become compulsory in 1882. The scheme, he argued, would have two main advantages: it would augment water use in poorer dwellings and it would provide the city with additional revenue that would be particularly helpful in raising new capital for expanding the existing distribution network. Nevertheless, the principle of compulsory subscription was resisted in the name of property rights under pressure from landowners who were supported by several lawyers who also sat on the City Council, 59 .

As regards network coverage, the water department decided to complete the network in central Paris before improving connections in peripheral neighborhoods, with the exception of

54 See K. Chatzis, “Brève histoire des compteurs...”, op. cit., p. 165-66.

55 See Michel Foucault, "The Subject and Power", in H. Dreyfus and P. Rrabinow, Michel Foucault: Beyond Structuralism and Hermeneutics, Chicago, The University of Chicago Pres, 1982, p. 208-226. Regarding the efforts of city engineers to "discipline" network users, who never ceased to find new ways of getting access to municipal water without paying the full cost throughout the nineteenth century, frequently in cahoots with city officials, see K. Chatzis, "Brève histoire des compteurs...”, op. cit.

56 "Regulation of July 25, 1880, concerning water subscriptions" (in Recueil des lois et décrets sur l'administration communale et départementale, Paris, 1885.) and "Traité du 20 mars 1880 entre la Ville de Paris et la Compagnie générale des Eaux" (in Recueil des lois..., op. cit) (articles 3 et 4). From the 1850s, the costs of installing private conduits to take water from the main public network was already covered by the Council if the annual amount of the subscription was more than one-fifth of the initial installation expenditure.

57 We should recall that the policy of installing standpipes free of charge had already been applied in Paris by the Compagnie du Gaz (gas board). See K. Chatzis et O. Coutard, "Water and Gas: Early Developments in the Utility Networks of Paris”, Journal of Urban Technology, vol. 12, $n^{\circ} 3,2005$, p. 1-17

58 Note the recycling of Haussmann's argument concerning non-compulsory schooling.

59 See Ph. Cebron de Lisle, L'eau..., op. cit., p. 548-549. 
the worst-served districts (Twelfth and Seventeenth arrondissements). Once again, the reasons concerned water quality. The centre of Paris could only draw on the waters of the Ourcq Canal for both public and private service where distinct canalization had not been introduced (one for spring water and one for water from the Ourcq). The engineer in charge of the water department at this time, a certain Couche, considered that it was more urgent to develop a network of spring water in central Paris, where there was none, than in outlying areas where it was already available, albeit to a limited extent. The decision to extend this network for distributing spring water to the periphery came later60.

To encourage private individuals to become subscribers, the City once again turned to incentive-based methods and in 1894 - the year in which connection to water borne sewage systems, requiring large quantities of running water in the home, became compulsory - a new regulation was passed concerning spring water. It did away with free-flow subscriptions completely and spring water could now only be delivered on a metered basis. However, the rate charged was much lower than in the past (about $20 \%$ less than in 1880). For the first time, the City broke with the principle of a single rate for a given type of water and began to offer owners of low-rent buildings special attractive rates or even the possibility of taking out flat rate subscriptions ${ }^{61}$.

All of these various incentives, which continued to be offered in the Inter-War period, ${ }^{62}$ finally began to bear fruit as shown in both the table of subscribers to the Service des Eaux (Table 3) and the table of consumption patterns (Table 4). The increase in the number of subscribers occurred alongside the more widespread use of metering which had become virtually the only method of taking out a subscription by the beginning of the twentieth century. This generalization of meter-based subscriptions had a huge positive impact on the revenues of the municipal water department which climbed from less than 9 million francs in 1878 , to a little over 19 million in 1899 . By the early twentieth century the City was in a position to cover the interest and depreciation charges on the loans contracted to develop the distribution network which was a necessary pre-condition for developing the subscriber base (concerning network development, see Table 3 and Map 2 (proportion of unconnected streets 1879-1887). A more detailed geographical analysis of the subscriber base (Table 5 and Map 3) shows that the global increase was reflected across all arrondissements and the number of subscribers grew at roughly the same rate until universal service was achieved at the end of the 1920s: those that had more subscribers in 1886, mainly the central and western arrondissements, achieved universalization first, but the others gradually caught up. The overall picture represents a success, not only in persuading the general public to become subscribers, but also in terms of the choices made concerning the coverage of the network to provide spring water.

\footnotetext{
60 Report of the Chief Engineer of the Water Department. Etude de l'achèvement de la distribution des eaux de Paris. Reports and documents, 1880 .

61 The work of the Commission on unhealthy housing (Comission des Logements Insalubres) appears to have been a determining factor in the introduction of these rates (Archives de la Seine, AS VO3 63), which were still in force in 1934: the regulation of September 4,1934 made metering compulsory for all types of water but provided for preferential rates for subscribers on low rents (article 11) (see E. Barberot, Traité pratique de la législation du bâtiment et des usines, Paris et Liège, Librairie polytechnique Ch. Béranger, 1946, p. 820).

62 Thus, in 1928, when there were still buildings in which certain floors were without running water, the Council offered to provide "smallholders" wishing to carry out the necessary work, with "loans repayable in yearly installments". See, Conseil municipal, Rapports et Documents, $n^{\circ}$ 95, 1928.
} 
Tableau 5

Ratio nombre d'abonnements sur nombre de propriétés bâties

\begin{tabular}{|l|c|c|c|c|}
\hline & $5^{\mathrm{e}}$ arrondissement & $9^{\mathrm{e}}$ arrondissement & $16^{\mathrm{e}}$ arrondissement & $20^{\mathrm{e}}$ arrondissement \\
\hline 1886 & 0,66 & 0,90 & 1,08 & 0,54 \\
\hline 1901 & 1,07 & 1,22 & 1,11 & 0,85 \\
\hline 1928 & 1,2 & 1,25 & 1,13 & 1,05 \\
\hline
\end{tabular}

Source : nos calculs d'après G. Bechmann, Rapport présenté par M. Deligny au nom de la

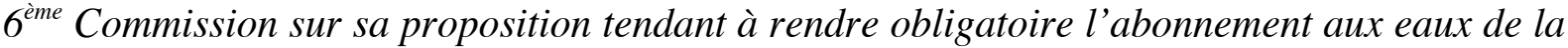
ville du 15/2/1887 (Rapport et Documents du Conseil municipal, 1887) et l' Annuaire statistique et descriptif..., de 1903 et 1931. 


\section{Map 3}

Ratio number of subscriptions / number of houses

(the darker the better connected)
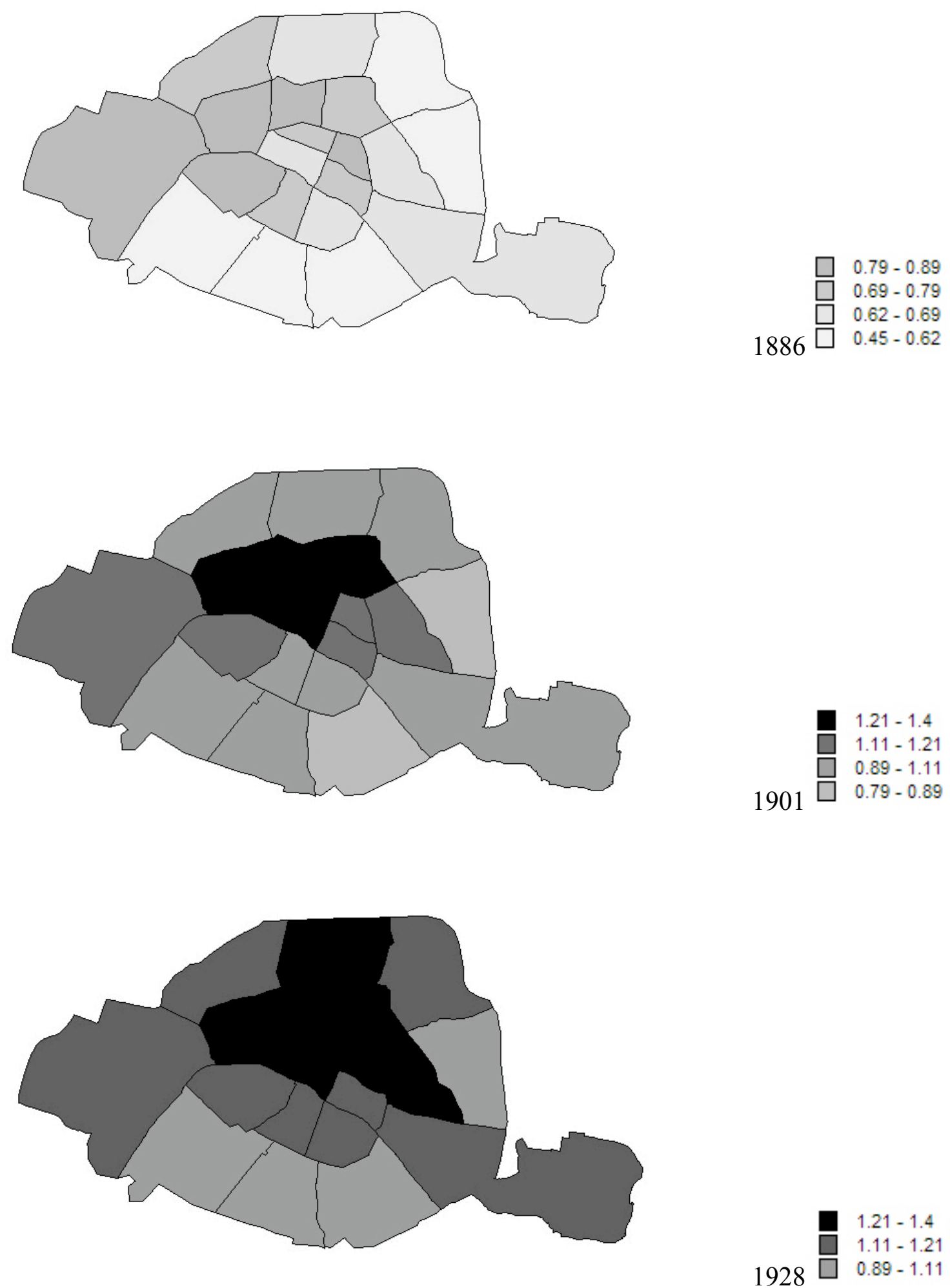

Data : Bechmann 1887 et l'Annuaire statistique et descriptif..., de 1903 et 1931 
Tableau 3

Nombre d'abonnements et longueur du réseau de 1876 à 1927

\begin{tabular}{|l|l|l|l|l|l|l|l|l|l|}
\hline Year & 1876 & 1879 & 1880 & 1885 & 1890 & 1895 & 1900 & 1906 & 1927 \\
\hline $\begin{array}{l}\text { Subscri } \\
\text { bers }\end{array}$ & 42520 & 46887 & 48400 & 64207 & 72538 & 79802 & 91388 & 103184 & 116159 \\
\hline $\begin{array}{l}\text { Lengh } \\
\text { of the } \\
\text { networ } \\
\mathrm{k}(\mathrm{km})\end{array}$ & 1397 & & 1527 & 1979 & 2125 & & & & 2774 \\
\hline
\end{tabular}

Sources : Bechman, Annuaire statistique et descriptif. 
Map 2

Proportion of unconnected streets $1879-1887$

(The clearer the better connected)
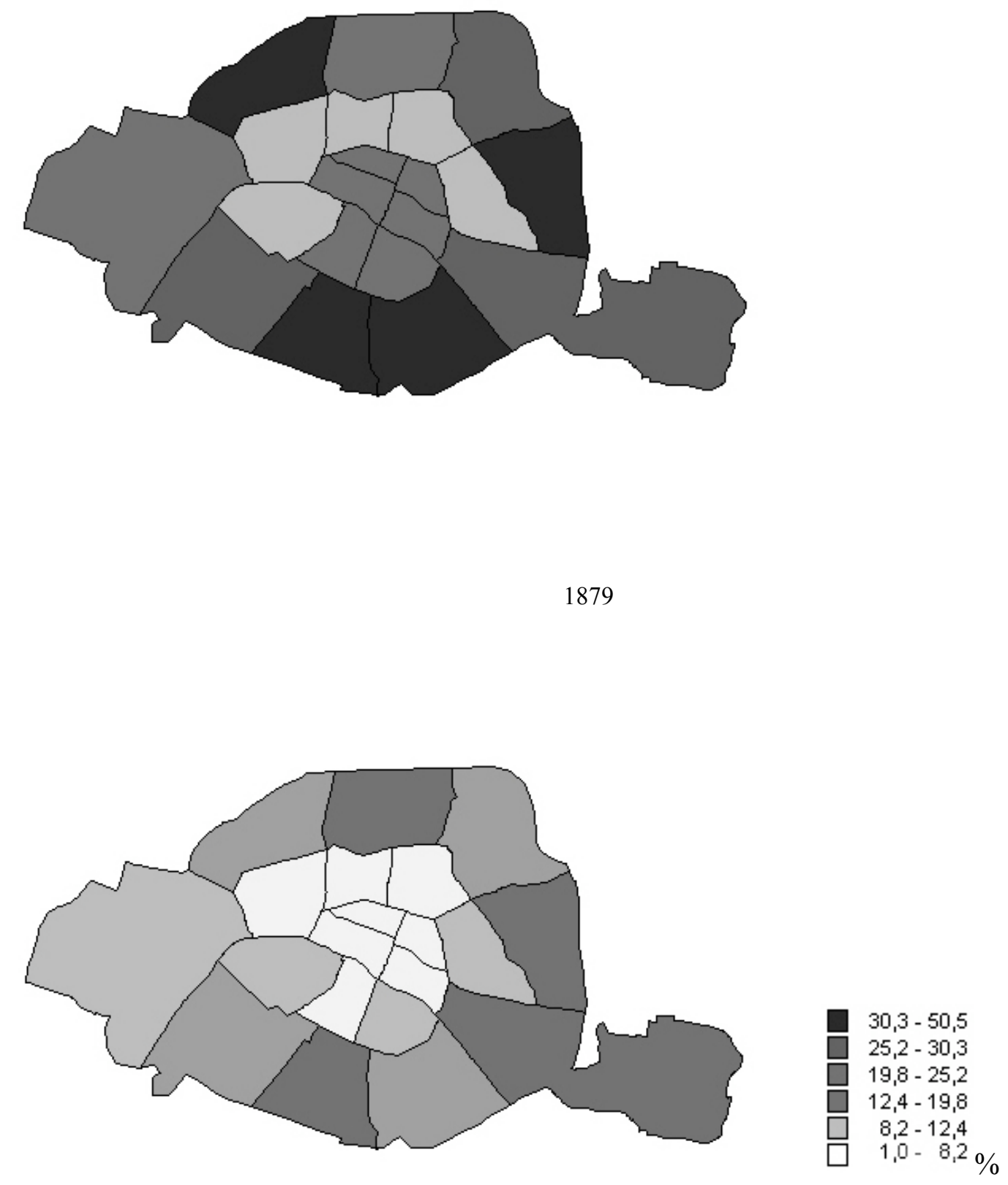
Lastly, the increase in the number of subscribers was accompanied by a corresponding decrease in the number of free street fountains (Table 1) which were considered one of the factors limiting the water department's efforts to develop its customer base. From the 1880s the very poor found it increasingly difficult to procure water, thence the recurring protests against the generalized use of water meters ${ }^{63}$. Thence, the advance towards the "bundled infrastructure" created victims among the poor who suffered from the long transition period from the old system of universalization (public fountains) to the new system of universalization (paying subscriber-based network).

How can we account for the decision of Paris property owners to sign up to the network in spite of their fierce opposition to compulsory subscriptions? A number of developments account for this change in attitude. We have already covered the incentives provided by the Council, particularly those dating from 1894, and we can also add two other significant factors. From the $1860 \mathrm{~s}$ on, there were important changes in the municipal sewage system that had positive repercussions on the number of water subscribers. In 1867, buildings equipped with "filtered latrines", i.e., a mechanism that separated liquid and solid household waste, were authorized to dispose of the liquid portion (i.e., wastewater) directly into the sewers. This system meant that the frequency (and costs) of emptying cesspools was now independent of the quantities of water consumed by tenants (see above), which allowed property owners to subscribe to the water network without any potential loss in rental income. The manner in which the property rental market functioned also helps account for landlord's change of heart. In light of the general changes in the views and behavior of Parisians (especially the better off) concerning cleanliness and hygiene at the turn of the century, taking out a subscription ultimately became a decisive weapon in the fight to get "good" tenants who were more and more eager to live in houses connected to the water network ${ }^{64}$.

\section{Conclusion}

At the beginning of our account, the inhabitants of Paris got their water from a few public fountains; by the end, they were all (or nearly all) connected to the municipal water network. While the authors of this article, like those of Splintering Urbanism, have a shared interest in the issue of the "modern infrastructural ideal, the approach used to tackle this issue is not the same. There is no mention here of any major macro-social categories like the Nation State or capitalism, but a whole multitude of actors with very different capacities to act, each of whom impacts "positively" or negatively" on the process of providing Parisians with universal access to a modern water distribution network.

They consisted primarily of "public" actors directly involved in running the city - municipal councilors and prefects (in Paris, the Prefect was also the mayor) - as well as the state engineers that ran and staffed the municipal water department. Once the initial infatuation with the British model based on handing out concessions to private entrepreneurs had waned,

\footnotetext{
63 See J. Csergo, Liberté, égalité..., op. cit., p. 324. See also the account of G. Bechmann, Salubrité urbaine..., op. cit., p. 518.

64 Certain property holders were quick to appreciate the benefits of connecting their building to the water network in order to hold on to "good" tenants. See, for example, the letter of a reader and property owner named Audibert published in La revue municipale, 16 décembre 1852, p. 912-913. In the same vein, many Parisian buildings in the late nineteenth and early twentieth century used little signs to inform passers-by that they were equipped with " water and gas on all floors".
} 
the bulk of these actors plumped for a municipal water distribution service. They devised numerous technical, organizational and financial innovations to provide this system with sufficient resources in pursuit of the ideal of a universal service network.

Alongside these actors, we also encountered private actors who were no less important. These included professionals working in the water sector ranging from small actors, such as water carriers and domestics, to major operators, like Compagnie Générale des Eaux, which took charge of "marketing" the municipal water service from the 1860 s on. Property owners who were initially reluctant, and even hostile to becoming water subscribers eventually climbed on board following several developments (changes in the municipal sewage system, incentives provided by the water department and competition to find decent tenants). And of course the consumers (be they landlords or tenants) that the water department and the hygienist movement of the period (another key actor in the process of universalization) frequently had to "train" to become "good" users of a modern water network by attempting, for example, to convince them of the need for abundant running water for corporal and public hygiene, or by attempting to make them "rational" in the manner in which they consumed a precious resource, often with the help of technical equipment like water meters.

We hope we have succeeded in demonstrating that the process of universalization, far from being the inexorable and linear outcome of the action of a small number of "major historical forces", was the upshot of the actions of a whole range of actors acting in specific different geographical, social, economic and technical contexts. The achievement of the "modern infrastructural ideal" as a macro-social phenomenon was ultimately down to a long accumulation process of a multitude of actions, interactions, conflicts and learning processes.

Does the change in the scale of our research vis-à-vis that adopted by the authors of Splintering Urbanism add more than mere descriptive detail? We consider that, although from a global perspective, Paris' experience was marked by fundamentally local factors and trends, an analysis of the underlying components of the development of the Parisian water network can still provide lessons of a more general nature concerning the development of the "modern infrastructural ideal", particularly by raising a series of issues to be explored in future comparative analyses.

Take the issue of the legal status of the water department (municipal service or private concession) in the process of universalization. The Paris experience blurs the public/private distinction as, beginning in the 1860s, it combined a municipal service acting in tandem with a private concession holder tasked with running the commercial side of operations, i.e., selling water on a subscription basis. The fact that the service was municipally run, as well as its stated desire to develop a universal network, evidenced by a plethora of actions that included laying pipes throughout the city's streets, were not sufficient factors for rapidly achieving the "modern infrastructural ideal" (as we have seen, may property holders long refused to connect their buildings up to the city's existing network). Why did Paris' municipal service fail where the privately-owned concession holders of London or the municipal service of the City of Montreal ${ }^{65}$ succeeded in rapidly developing a large base of water subscribers? It was not the legal status of the management company, but its ability to enforce compulsory subscription to the network (in London and Montreal) or its failure to do so (in Paris) that appeared to be the determining factor.

65 Concerning Montréal, see Dany Fougères, L'approvisionnement en eau à Montréal. Du privé au public, 1796-1865, Sillery (Québec), Editions du Septentrion, 2004. 
The issue of "compulsory subscription" leads us on to another series of processes and variables that play a key role in the creation of a "bundled infrastructure", namely, property holders and their practices. Why did Paris property owners hold out for so long before signing up to the network? We have seen that waste water disposal methods (yet another infrastructure) in Paris both before the introduction of "filtered latrines" and water borne sewage systems (law of 1894) held back the development of subscriptions. We also believe that the development of the "modern infrastructure ideal" was hindered by the types of subscription offered in Paris. It is worth recalling that after the introduction of the water meter, the amount that property owners paid to the water department was based on the volume consumed by the tenant(s), whereas in London or Montreal, such amounts were calculated on the rental value of property, i.e., independently of the quantity consumed by the tenant ${ }^{66}$. Perhaps this explains the reluctance of Parisian landlords to take out a subscription that would only make managing their property more complicated and the development by these same landlords of numerous practices for controlling and even arbitrarily restricting their tenants' water consumption 67 . Based on the singular case of Paris, types of subscriptions and the structures of holdings (concentrated or not, etc.) also appeared to be general variables in the network development process.

Lastly, this account stresses another general phenomenon that is not specific to Paris: the existence of "vicious circles" (for periods in which the subscriber base stagnates) or "virtuous circles" (when the number of new subscribers is increasing rapidly) which combined and succeeded each other and account for the pace of urban technical network development. Let us compare the period 1831-1854, when it took 23 years for the number of subscribers to get from 921 to 7,633 (291 new subscriptions a year), with the period 1890-1906 when, in the space of just 16 years, the subscriber base soared from 72,538 to 103,184 (1,915 subscriptions a year, i.e., six times as many as in the period 1831-1854). From 1890, we may consider that the virtuous circle phenomenon kicked in: "a sufficient number of subscribers generating enough income to extend the network and provide incentives that in turn attract new subscribers, etc." This came after the less heady periods in which there were "a limited number of subscribers and thence insufficient income for extending the network or developing incentive policies (lower rates, free connections, etc.) to attract new subscribers". Aside from the type of management company, it is easier to develop the network and the subscriber base in the virtuous circle phase and more difficult when it is first necessary to emerge from a period of sluggish network development. It makes no more sense to idealize institutions and firms that succeed in "virtuous circle" periods than to conclude that those who have to work in a more difficult environment have failed in the short term.

\footnotetext{
66 We should note that before the advent of metering, the Parisian landlord was indifferent to the quantity of water consumed by his tenants as the amount of the subscription (paid for by the tenant) was set ad infinitum and therefore consisted of a fixed charge whether it was set on a free-flow or a gauging basis.

67 Concerning this phenomenon, see K. Chatzis, "Brève histoire des compteurs...”, op. cit.
} 


\section{Graph 1}

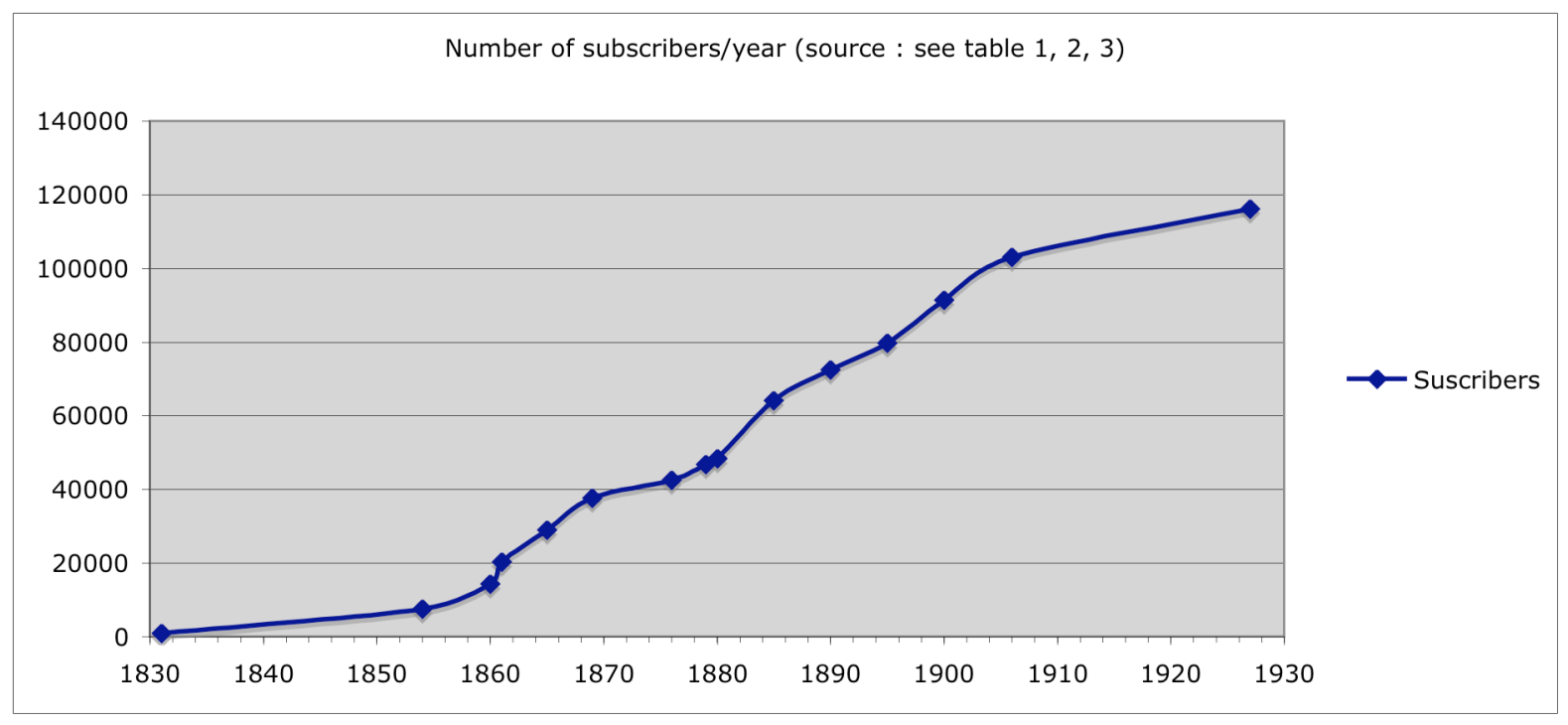

Therefore, we have attempted to demonstrate that a "case study" can tackle general issues by identifying the "micro-processes" and variables encountered individually in other contexts other than in the case in point. A comparative analysis of several such cases will have to be carried out to deal with the issues highlighted and to rank the relative importance of the different "processes" and "variables" identified in the explanation of a macro-social phenomenon such as the realization of the "modern infrastructural ideal." 68

68 Comparative analyses may already draw on a body of accumulated existing research available to the historian. See, inter alia, the following works which contain extensive bibliographies: Martin Melosi, The sanitary city: urban infrastructure in America from colonial times to the present. Creating the North America landscape, Baltimore, 2000; Jean-Pierre Goubert, La conquête de l'eau, Robert Laffont, Paris, 1986; Dany Fougères, L'approvisionnement en eau à Montréal. Du privé au public, 1796-1865, Sillery (Québec), Editions du Septentrion, 2004; Denis Bocquet and Samuel Fettah (dir.), Réseaux techniques et conflits de pouvoir. Rome, Ecole française de Rome, 2007. 